DOI 10.14746/ssp.2020.1.7

Renata GABRYSZAK

Politechnika Koszalińska

ORCID: 0000-0003-2739-8744

\title{
Społeczny model niepełnosprawności a lokalny system wsparcia osób niepełnosprawnych na przykładzie działań Miejskiego Ośrodka Pomocy Rodzinie w Koszalinie w latach 2013-2016
}

Streszczenie: Społeczny model niepełnosprawności stanowi obecnie w przestrzeni europejskiej dominującą perspektywę podejścia do istoty niepełnosprawności oraz osób nią dotkniętych. Polska, przyjmując w 1997 roku Uchwałą Sejmu Kartę Praw Osób Niepełnosprawnych oraz przystępując w 2012 roku do Konwencji o prawach osób niepełnosprawnych, zobowiązała się do przyjęcia tej perspektywy w swoich regulacjach i działaniach na rzecz osób z niepełnosprawnościami. Celem artykułu była analiza i ocena działań Miejskiego Ośrodka Pomocy Rodzinie w Koszalinie w latach 2013-2016, jako kluczowej instytucji w lokalnym systemie wsparcia osób niepełnosprawnych. Dla realizacji tak sformułowanego celu przyjęto następującą tezę: na poziomie lokalnym polski system instytucjonalnego wsparcia osób niepełnosprawnych nie realizuje w pełni założeń społecznego modelu niepełnosprawności. Przeprowadzona w artykule charakterystyka działań MOPR w Koszalinie zweryfikowała ją pozytywnie, wskazując na prawno-instytucjonalne bariery w skutecznej pomocy osobom niepełnosprawnym zgodnie ze społecznym modelem niepełnosprawności.

Słowa kluczowe: niepełnosprawność, społeczny model niepełnosprawności, polityka społeczna, rehabilitacja, wsparcie osób niepełnosprawnych

\section{Wprowadzenie}

Tiepełnosprawność, oprócz swojego indywidualnego wymiaru, roz- patrywana jest również jako kwestia społeczna, czyli taka kategoria problemu, która jest szczególnie dotkliwa dla życia i współdziałania członków danej zbiorowości (Danecki, 2001, s. 71-78) i jako taka, stanowi pole zainteresowania polityki społecznej.

Charakter tego zainteresowania ewoluował wraz ze zmieniającym się stosunkiem do istoty niepełnosprawności oraz osób nią dotkniętych. 
Ewolucja tego podejścia przebiegała od medycznego modelu tego zjawiska, czyli koncentracji na organizmie (ciele) jednostki i jej deficytach nie mieszczących się w „,normie”, do modelu społecznego, czyli uznania, iż niepełnosprawność tworzą przede wszystkim warunki środowiska społecznego i fizycznego ograniczające tym osobom pełnienie ról społecznych (Klimczuk, 2013, s. 191; Kubicki, 2015, s. 14). Uznanie określonego modelu za zasadniczy punkt wyjścia w projektowaniu działań polityki społecznej wobec osób niepełnosprawnych ma zasadniczy wpływ na instrumentarium przyjęte przez tę politykę.

Rehabilitacja, opieka oraz pomoc socjalna to główne narzędzia polityki społecznej opartej o medyczny model niepełnosprawności (Świetlik, 2018, s. 15), natomiast włączenie, równość dostępu (do edukacji, rynku pracy, życia w przestrzeni publicznej we wszystkich jej wymiarach) oraz integracja to fundamentalne zadania tej polityki realizującej społeczny model niepełnosprawności (Kolwitz, Radlińska, 2015, s. 274). Obecnie to ten ostatni stanowi dominującą perspektywę w europejskich politykach społecznych, zarówno na poziomie strategii i planów, jak i stosowanych narzędzi do ich realizacji (zob. Gelleta, Grewiński, 2014, s. 7).

$\mathrm{W}$ polskim systemie prawno-instytucjonalnym, zgodnie $\mathrm{z}$ zasadą decentralizacji będącą praktycznym urzeczywistnieniem idei subsydiarności (Supińska, 2015, s. 78), realizacja założeń polityki społecznej, również wobec osób z niepełnosprawnościami, odbywa się na różnych szczeblach administracji rządowej i samorządowej.

Instytucją, która na szczeblu lokalnym w głównej mierze zobligowana jest do wykonywania zadań z zakresu polityki społecznej, w tym pomocy i rehabilitacji społecznej osób niepełnosprawnych, są miejskie (gminne) ośrodki pomocy rodzinie (M/GOPR) (Florek-Łuszczki, Lachowski, 2013, s. 482).

Celem artykułu jest charakterystyka i ocena funkcjonowania instytucjonalnego systemu wsparcia osób niepełnosprawnych na szczeblu lokalnym w kontekście dostosowania go do społecznego modelu niepełnosprawności. Za przedmiot analizy wybrano miejski ośrodek pomocy rodzinie, który poprzez prawnie przypisane kompetencje i obowiązki jest w tym systemie instytucją kluczową.

Realizacja tak zarysowanego celu osiągnięta zostanie poprzez weryfikację następującej tezy: Na poziomie lokalnym polski system instytucjonalnego wsparcia osób niepełnosprawnych nie realizuje w pełni założeń społecznego modelu niepełnosprawności. 
W części teoretycznej artykułu zastosowana została krytyczna analiza wybranych pozycji literatury przedmiotu, natomiast w części empirycznej posłużono się analizą przypadku, do której wybrano Miejski Ośrodek Pomocy Rodzinie w Koszalinie, wykorzystując sprawozdania z jego działalności za lata 2013-2016.

\section{Niepełnosprawność i modele niepełnosprawności. Kwestie terminologiczne}

W zależności od przyjętego podejścia i kontekstu, niepełnosprawność definiowana jest w bardzo różnorodny sposób. Najczęściej funkcjonujące w przestrzeni teoretyczno-prawnej definicje niepełnosprawności reprezentują dwa, podstawowe podejścia do tej kwestii (Woźniak, 2008, s. 27-28): medyczne oraz społeczne (Giełda, 2015, s. 26; Bieganowska, 2015, s. 14; Barnes, Mercer, 2008, s. 7; Karaś, 2012, s. 4). To pierwsze koncentruje się na indywidualnym wymiarze niepełnosprawności i, w zależności od punktu widzenia, odwołuje się do takich pojęć jak choroba, uszkodzenie czy zaburzenie oraz opieka i rehabilitacja (Wiliński, 2010, s. 32-34).

Podejście medyczne jest pierwotnym spojrzeniem na istotę niepełnosprawności, wiążąc ją z kategoriami upośledzenia i utrudnienia (Wiliński, 2010, s. 18). Ta perspektywa stanowi źródło definicji przyjętych przez jedną z najważniejszych organizacji międzynarodowych i jej agendę, czyli Organizację Narodów Zjednoczonych (ONZ) oraz Światową Organizację Zdrowia (WHO).

Według tej ostatniej istotę niepełnosprawności, według przyjętej w roku 1980 definicji, można opisać za pomocą związanych ze sobą i współoddziałujących na siebie, następujących kategorii. Po pierwsze, utraty sprawności lub nieprawidłowości w budowie lub funkcjonowaniu organizmu pod względem anatomicznym, psychofizycznym lub psychologicznym. Po drugie, każdego ograniczenia lub niemożności prowadzenia aktywnego życia w sposób uznawany za typowy dla człowieka. I po trzecie, utrudnienia (upośledzenia) w pełnieniu ról społecznych, czyli ułomności określonej osoby wynikającej z niesprawności lub niepełnosprawności, która ogranicza lub uniemożliwia pełną realizację ról społecznych odpowiadających wiekowi, płci oraz zgodną z uwarunkowaniami społecznymi i kulturowymi (Vademecum, 2009, s. 9).

Podejście z perspektywy medycznej do niepełnosprawności reprezentuje również definicja zawarta w Konwencji o Prawach Osób Nie- 
pełnosprawnych przyjęta przez Zgromadzenie Ogólne ONZ 13 grudnia 2006 roku. Mówi ona, iż niepełnosprawną jest osoba, która ma trwale naruszoną sprawność fizyczną, umysłową, intelektualną lub w zakresie zmysłów, co może w połączeniu z innymi barierami utrudniać jej pełny i skuteczny udział w życiu społecznym na zasadzie równości z innymi osobami (Konwencja).

Społeczny model niepełnosprawności niejako odwraca perspektywę spojrzenia na jej istotę, zwracając przede wszystkim uwagę na otoczenie społeczne, które uniemożliwiając osobie z dysfunkcjami fizycznymi/psychicznymi pełnienie podstawowych ról społecznych czyni z niej osobę niepełnosprawną. Model ten, opierając się na takich pojęciach jak opresja, bariera czy wykluczenie, uznaje zatem, iż źródłem niepełnosprawności nie jest samo „uszkodzenie”, ale organizacja i warunki otoczenia społecznego oraz stosunek jego członków do osoby niepełnosprawnej (Waszczak, 2000, s. 92).

Do perspektywy społecznej nawiązuje wiele współcześnie formułowanych definicji niepełnosprawności. Jedną z nich jest definicja brytyjskiego stowarzyszenia zrzeszającego osoby niepełnosprawne (Union of Physically Impaired Against Segregation - UPIAS), według której niepełnosprawność to ,[...] niedogodność albo ograniczenie aktywności spowodowane przez współczesną społeczną organizację, która nie bierze w ogóle lub w niewielkim stopniu pod uwagę ludzi, którzy mają uszkodzenia lub wady fizyczne wskutek tego wyklucza ich z uczestnictwa w głównym nurcie aktywności społecznej” (Gąciarz, 2014, s. 19). Kolejna z definicji oparta na społecznym modelu niepełnosprawności sformułowana została w roku 1994 przez Europejskie Forum Niepełnosprawności. Według niej „osobą niepełnosprawną jest jednostka w pełni swych praw, znajdująca się w sytuacji upośledzającej ją na skutek barier środowiskowych, ekonomicznych i społecznych, których z powodu występujących u niej uszkodzeń nie może przezwyciężać w taki sposób jak inni ludzie. Bariery te zbyt często są zwiększane przez deprecjonujące postawy ze strony społeczeństwa. Do zadań społeczeństwa należy eliminowanie, zmniejszanie lub kompensowanie tych barier, aby każdej jednostce umożliwić korzystanie z dóbr publicznych jednocześnie respektując jej prawa i przywileje" (Gałkowski, 1997, s. 32).

Mariaż perspektywy medycznej i społecznej, przenoszący indywidualny wymiar niepełnosprawności w przestrzeń życia zbiorowego, stanowi dzisiaj podstawę europejskich polityk społecznych. Oprócz działania systemu indywidualnej pomocy osobom z niepełnosprawnościami, główny 
nacisk kładzie się w nich na zmiany w przestrzeni publicznej, dostosowujące ją do ich potrzeb.

Przykładem rozwiązań, które założenia społecznego modelu niepełnosprawności wprowadzają do praktyki działania systemów wsparcia osób niepełnosprawnych, jest m.in. instytucja osobistego asystenta, funkcjonująca w systemie niemieckim, francuskim czy szwedzkim. Co istotne, jego pracodawcą jest sama osoba z niepełnosprawnością, co daje jej poczucie sprawstwa i kontroli nad swoim życiem. Podobną funkcję pełnią tzw. budżety osobiste, czyli środki finansowe pozostawiane do dyspozycji osoby niepełnosprawnej, która z zachowaniem wolności wyboru, ale i prawa, może wydać je na własne potrzeby związane z najszerzej pojętą rehabilitacją. Taka forma wsparcia funkcjonuje m.in. we Francji, Niemczech czy Wielkiej Brytanii (więcej: Woźniak-Szymańska, 2011, s. 22-44; Asystent, 2014, s. 9-10, 71).

W Polsce obowiązującą definicją niepełnosprawności jest ta zawarta w ustawie z dnia 27 sierpnia 1997 roku o rehabilitacji zawodowej i spotecznej oraz zatrudnianiu osób niepetnosprawnych, według której niepełnosprawność jest „trwałą lub okresową niezdolnością do wypełniania ról społecznych z powodu stałego lub długotrwałego naruszenia sprawności organizmu, w szczególności powodującą niezdolność do pracy" (Ustawa 1). Niezdolność ta potwierdzona musi być orzeczeniami o zakwalifikowaniu przez organy orzekające do jednego z trzech stopni niepełnosprawności lub o całkowitej lub częściowej niezdolności do pracy na podstawie odrębnych przepisów albo o niepełnosprawności, wydanym przed ukończeniem 16. roku życia (Brazkowski, 2014, s. 5).

Powyższe zapisy w sposób formalny określają tzw. niepełnosprawność prawną, czyli legitymowaną odpowiednimi dokumentami, stąd dość znacznie odbiegają one od społecznego kontekstu tego zjawiska.

Bliższą społecznemu modelowi niepełnosprawności definicję zawarto w Karcie Praw Osób Niepełnosprawnych, która uchwalona została przez Sejm RP 1 sierpnia 1997 roku. Według jej zapisów niepełnosprawnością jest sytuacja, która utrudnia, ogranicza, lub uniemożliwia życie codzienne, naukę, pracę oraz pełnienie ról społecznych, zgodnie z normami prawnymi i zwyczajowymi (Uchwała).

Swoją definicją niepełnosprawności posługuje się Główny Urząd Statystyczny, który obok niepełnosprawności prawnej, wprowadza kategorię niepełnosprawności biologicznej, oznaczającą sytuację, w której osoba odczuwa całkowicie lub poważnie ograniczoną zdolność do wykonywania podstawowych czynności życiowych. 


\section{Dzialania MOPR w Koszalinie na rzecz osób niepelnosprawnych w latach 2013-2016}

Według polskiego prawa, podstawowym instrumentem realizowania polityki społecznej jest pomoc społeczna, którą na poziomie samorządowym wykonują miejskie (powiatowe) centra pomocy rodzinie (Ustawa 2, art. 2.1, 112.1]. Przepisy ustawy definiują pomoc społeczną jako działania umożliwiające osobom i rodzinom przezwyciężanie trudnych sytuacji życiowych, których nie są w stanie samodzielnie pokonać przy wykorzystaniu własnych uprawnień, zasobów i możliwości. Wśród wielu powodów przyznania pomocy ustawa wymienia również niepełnosprawność [ibidem, art. 7].

Z kolei aktem dedykowanym jedynie osobom o ograniczonej sprawności jest wspomniana ustawa z dnia 27 sierpnia z 1997, która nakłada na miejskie ośrodki pomocy rodzinie obowiązki m.in. związane z: rehabilitacją społeczną, przestrzeganiem praw osób niepełnosprawnych, podejmowaniem działań zmierzających do ograniczania skutków niepełnosprawności czy dofinansowywaniem działań związanych z rehabilitacją społeczną, co czyni z nich kluczowy element lokalnych systemów wsparcia dla tych osób (Ustawa 1, art. 35a1).

Zacytowane wcześniej definicje dość znacznie odbiegają od siebie, co m.in. wpływa na trudności w precyzyjnym określeniu rozmiaru zjawiska niepełnosprawności w skali ogólnokrajowej, regionalnej i lokalnej. Swoimi zbiorami danych dysponują Główny Urząd Statystyczny, Zakład Ubezpieczeń Społecznych, a w skali regionalnej - Miejskie (Powiatowe) Zespoły ds. Orzekania o Niepełnosprawności.

Według danych z Narodowego Spisu Powszechnego przeprowadzonego przez GUS w 2011 roku, Koszalin zamieszkiwało 13580 osób niepełnosprawnych, z czego niepełnosprawnych prawnie (czyli legitymujących się orzeczeniem o niepełnosprawności) - 8658 osób, co oznacza, że w momencie spisu ponad $36 \%$ niepełnosprawnych koszalinian odczuwających znaczną lub całkowitą niezdolność do wykonywania podstawowych czynności życiowych nie miało na to żadnego potwierdzenia odpowiednich instytucji. Według tych danych, populacja niepełnosprawnych stanowiła ok. 12\% ogółu mieszkańców Koszalina (GUS, 2011).

Aktualniejszych informacji dostarczają dane Miejskiego Zespołu ds. Orzekania o Niepełnosprawności w Koszalinie. W latach 2013-2016 Zespół wydał łącznie 7464 orzeczeń, z czego tych po raz pierwszy - 2657. Wśród nich decyzje o znacznym stopniu niepełnosprawności stanowiły w anali- 
zowanych latach od 24\% do niemal 30\% orzeczeń ogółem (w roku 2013 -25,9\%, $2014-26 \%, 2015-29,9 \%$, w $2016-28,3 \%$ ) (Informacja, s. 5-7).

W lokalnych systemach pomocy wydanie orzeczenia o niepełnosprawności uruchamia dalsze działania pomocowe, zarówno materialne, jak i obejmujące rehabilitację społeczną i zawodową. Większość z nich realizowana jest przez miejskie ośrodki pomocy rodzinie.

Zasiłek pielęgnacyjny ${ }^{1}$ oraz świadczenie pielęgnacyjne ${ }^{2}$ to główne instrumenty pomocy materialnej dedykowane osobom niepełnosprawnym oraz rodzinom, w których funkcjonuje osoba niepełnosprawna. Ich skalę na terenie Koszalina zobrazowano na wykresie 1.

\section{Wykres 1. Pomoc materialna dla osób niepełnosprawnych realizowana przez MOPR w Koszalinie w latach 2013-2016}

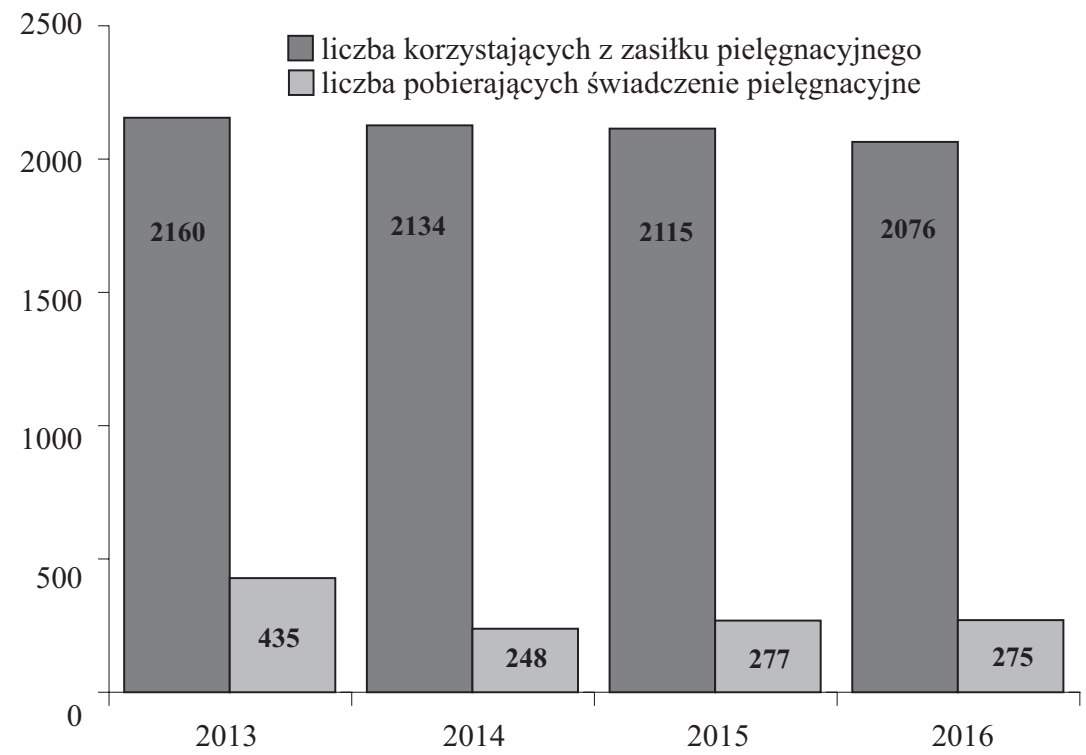

Źródło: Opracowanie własne na podstawie: Sprawozdanie z działalności Miejskiego Ośrodka Pomocy Rodzinie w Koszalinie za 2015, 2016 rok, s. 26 (2015), 28 (2016).

${ }^{1}$ Zasiłek pielęgnacyjny jest świadczeniem przyznawanym osobie niepełnosprawnej poniżej 16 roku życia oraz osobie niepełnosprawnej, która ten wiek ukończyła i legitymuje się orzeczeniem o znacznym stopniu niepełnosprawności. W roku 2016 jego wysokość wynosiła 153 zł na miesiąc.

2 Świadczenie pielęgnacyjne stanowi rekompensatę rezygnacji lub niepodjęcia pracy przez jednego z rodziców (lub opiekunów) w celu sprawowania opieki nad osobą niepełnosprawną. W roku 2016 jego wysokość wynosiła 1300 zł na miesiąc. 
Z tytułu niepełnosprawnści pomocą MOPR w Koszalinie objętych zostało w 2013 roku 1285 rodzin, w 2014 roku - 1230 rodzin, w roku następnym 1167 rodzin, a w 2016 roku - 1093 rodziny. Stanowiły one odpowiednio: 43, 49, 49 i 50\% ogólnej populacji rodzin korzystających z pomocy, co oznacza, że niepełnosprawność była jednym z głównych powodów przyznawania wsparcia $\mathrm{w}$ omawianych latach. Jednocześnie należy zwrócić uwagę na dość znaczny spadek liczby osób objętych wsparciem finansowym z tytułu niepełnosprawności. Tłumaczyć to można m.in. znaczną poprawą sytuacji gospodarczej w Polsce w ostatnich dwóch latach omawianego okresu, która, z jednej strony skutkowała spadkiem bezrobocia i poprawą materialnej sytuacji osób (rodzin), w tym osób niepełnosprawnych, z drugiej, brakiem waloryzacji progów dochodowych uprawniających do pobierania świadczenia przy jednoczesnym wzroście płacy minimalnej.

Oprócz wsparcia materialnego, koszaliński MOPR realizuje szereg zadań z zakresu rehabilitacji społecznej osób niepełnosprawnych. Przybiera ona przede wszystkim formę dofinansowania do sprzętu rehabilitacyjnego i ortopedycznego, a także do likwidacji barier architektonicznych w komunikowaniu się i technicznych oraz organizacji warsztatów terapii zajęciowej i turnusów rehabilitacyjnych. Jednocześnie należy zaznaczyć, że MOPR gra tu rolę, w pierwszym przypadku, redystrybutora środków przekazywanych przez Państwowy Fundusz Rehabilitacji Osób Niepełnosprawnych (PFRON), w drugim - merytorycznego nadzoru nad wykonawcą. W tabeli 1 przedstawiono liczbę osób, które skorzystały z tych instrumentów pomocy w latach 2013-2016.

Tabela 1

Zadania z zakresu rehabilitacji społecznej zrealizowane przez MOPR w Koszalinie w latach 2013-2016

\begin{tabular}{|c|c|c|c|c|}
\hline \multirow{2}{*}{ Zadanie } & 2013 & 2014 & 2015 & 2016 \\
\hline & \multicolumn{4}{|c|}{ liczba osób niepełnosprawnych } \\
\hline \multirow{3}{*}{$\begin{array}{l}\text { Dofinansowanie do sprzętu rehabilita- } \\
\text { cyjnego i ortopedycznego }\end{array}$} & 229 & 283 & 292 & 164 \\
\hline & \multicolumn{4}{|c|}{ wydatkowana kwota $w$ tys. zl } \\
\hline & 258 & 381,4 & 507,3 & 334,6 \\
\hline \multirow{4}{*}{$\begin{array}{l}\text { Dofinansowanie likwidacji barier ar- } \\
\text { chitektonicznych w komunikowaniu } \\
\text { się i technicznych }\end{array}$} & \multicolumn{4}{|c|}{ liczba osób niepełnosprawnych } \\
\hline & 54 & 24 & 4 & 11 \\
\hline & \multicolumn{4}{|c|}{ wydatkowana kwota w tys. zl } \\
\hline & 139,1 & 59,6 & 19,5 & 98,4 \\
\hline \multirow{2}{*}{ Warsztaty terapii zajęciowej } & \multicolumn{4}{|c|}{ liczba osób niepełnosprawnych } \\
\hline & 103 & 107 & 107 & 118 \\
\hline
\end{tabular}




\begin{tabular}{||c|c|c|c|c||}
\hline \multirow{4}{*}{ Turnusy rehabilitacyjne } & \multicolumn{4}{|c||}{ liczba osób niepelnosprawnych } \\
\cline { 2 - 5 } & 103 & 73 & 56 & 51 \\
\cline { 2 - 5 } & liczba opiekunów osób niepelnosprawnych \\
\cline { 2 - 5 } & 55 & 60 & 44 & 44 \\
\hline
\end{tabular}

Źródło: Opracowanie własne na podstawie: Sprawozdanie z działalności Miejskiego Ośrodka Pomocy Rodzinie w Koszalinie za 2015, 2016 rok, Koszalin 2016, 2017, s. 42 (2015), 43 (2016).

Porównując dane z tabeli 1 i wykresu 1, oraz informacji o liczbie rodzin, które uzyskały wsparcie finansowe w ramach pomocy społecznej (z tytułu niepełnosprawności) i liczbie osób niepełnosprawnych, które skorzystały z różnych form pomocy z zakresu integracji społecznej, okazuje się, iż skala tej ostatniej była niewspółmiernie mała do liczebności populacji objętej stricte socjalnymi transferami.

Oprócz działań z zakresu rehabilitacji społecznej przewidzianych ustawą, w Koszalinie realizowany był również pilotażowy, samorządowy program wsparcia osób niepełnosprawnych w tej sferze, pt. „Aktywny Samorząd", którego jednym z wykonawców był koszaliński MOPR ${ }^{3}$.

Głównym celem programu było zmniejszenie barier ograniczających uczestnictwo osób niepełnosprawnych w życiu społecznym, zawodowym i w dostępie do edukacji. Na poziomie praktycznym działania te przybrały formę indywidualnego, materialnego wsparcia na zrealizowanie określonych potrzeb osób niepełnosprawnych. Ich katalog przedstawiono w tabeli 2.

Przeprowadzona charakterystyka aktywności koszalińskiego MOPR na rzecz osób niepełnosprawnych wskazuje na znaczną ich różnorodność. Jednocześnie należy zwrócić uwagę na fakt, iż nałożone na tę instytucję zadania i kompetencje są o wiele szersze, więc działania z zakresu rehabilitacji społecznej stanowią jedynie wąski wycinek jej działalności.

Biorąc pod uwagę przedstawione dane należy zauważyć, iż w analizowanych latach skala pomocy spadła, a w niektórych formach wsparcia spadek ten był znaczący.

W roku 2016 (w stosunku do roku 2013) o ponad 36 punktów procentowych obniżyła się liczba osób pobierających świadczenie rehabilitacyjne, znacznie, bo niemal o połowę zmalała również liczba osób uczestniczących w turnusach rehabilitacyjnych. Podobna sytuacja dotyczyła także ograniczania barier edukacyjnych (spadek objętych pomocą o ponad 60 punktów procentowych), czy barier architektonicznych, transpor-

\footnotetext{
3 Program finansowany był $\mathrm{z}$ funduszy PFRON.
} 
towych, w komunikowaniu się i poruszaniu (średni spadek w roku 2016 w stosunku do roku 2013 wyniósł 82 punkty procentowe).

Tabela 2

\section{Działania MOPR w Koszalinie w ramach programu „Aktywny Samorząd” w latach 2013-2016}

\begin{tabular}{|c|c|c|c|c|}
\hline \multirow{2}{*}{ Zadanie } & 2013 & 2014 & 2015 & 2016 \\
\hline & \multicolumn{4}{|c|}{ liczba osób niepełnosprawnych } \\
\hline Ograniczanie barier transportowych* & 6 & 2 & 0 & 1 \\
\hline \multirow{2}{*}{$\begin{array}{l}\text { Ograniczanie barier w dostępie do uczestniczenia w } \\
\text { społeczeństwie informacyjnym** }\end{array}$} & \multicolumn{4}{|c|}{ liczba osób niepelnosprawnych } \\
\hline & 13 & 14 & 0 & 12 \\
\hline \multirow{2}{*}{ Likwidacja barier w poruszaniu się*** } & \multicolumn{4}{|c|}{ liczba osób niepełnosprawnych } \\
\hline & 4 & 6 & 2 & 8 \\
\hline \multirow{2}{*}{ Ograniczenie barier edukacyjnych**** } & \multicolumn{4}{|c|}{ liczba osób niepełnosprawnych } \\
\hline & 104 & 87 & 71 & 41 \\
\hline
\end{tabular}

* pomoc w zakupie i montażu oprzyrządowania do posiadanego samochodu; pomoc w uzyskaniu prawa jazdy kategorii B; ** pomoc w zakupie sprzętu elektronicznego lub jego elementów oraz oprogramowania oraz szkolenia w zakresie obsługi nabytego w ramach programu sprzętu elektronicznego; *** pomoc w utrzymaniu sprawności technicznej posiadanego wózka inwalidzkiego, pomoc w zakupie protezy kończyny, pomoc w utrzymaniu sprawności technicznej posiadanej protezy kończyny; **** dofinansowanie lub refundacja kosztów uzyskania wykształcenia na poziomie wyższym.

Źródło: Opracowanie własne na podstawie: Sprawozdanie z działalności Miejskiego Ośrodka Pomocy Rodzinie w Koszalinie za 2013, 2014, 2015, 2016 rok, Koszalin 2014, 2015, 2016, 2017, s. 43, 48 (2016).

Stosunkowo niewielka i systematycznie spadająca skala pomocy z zakresu integracji społecznej osób niepełnosprawnych wskazuje na jej systemowo-administracyjne słabości. Jej źródeł upatrywać należy m.in. w takiej organizacji systemu, która:

- po pierwsze łączy w jednej instytucji pomoc socjalną z działaniami integracyjnymi. Ta pierwsza wymaga bowiem skrupulatności i maksymalnego formalizmu, druga natomiast odpowiedniej dozy elastyczności i kreatywności. Jednocześnie przyczynia się to do utożsamiania polityki społecznej z pomocą społeczną, co w konsekwencji - sprowadza pomoc osobom niepełnosprawnym do opieki, a nie aktywizacji (Wóycicka, 2010, s. 84-96);

- po drugie zakłada negatywną formę weryfikacji uprawnień do skorzystania z określonych instrumentów wsparcia poprzez wyznaczanie takich kryteriów dostępu jak orzeczenie o stopniu niepełnosprawności czy limity dochodowe. Mechanizmy te, o segregacyjnym charakterze, 
w praktyce pełnią funkcję ograniczania dostępu do świadczeń (zob. Gąciarz, Kubicki, Rudnicki, 2014, s. 119);

- po trzecie nie wspomaga, a wręcz nie zakłada współpracy między podmiotami tworzącymi ten system. Prowadzi to do sytuacji, w której osoba niepełnosprawna na każdym etapie swojego życia spotyka się ze swoistymi podsystemami pomocowymi, które wyznaczają własne zasady i kryteria udzielania wsparcia. Rodzi to ryzyko powstawania tzw. węzłów krytycznych, tj. determinant dalszych możliwości integracji społecznej ich beneficjenta (ibidem, s. 117);

- po czwarte wreszcie, poprzez system orzeczniczy, który mając negatywny charakter i postrzegając osobę niepełnosprawną przez pryzmat jej deficytów i ograniczeń, a nie możliwości, tworzy warunki dla segregacji i podziału, zamiast sprzyjać integracji (Golinowska, Sowa, Wilmowska-Pietruszyńska, 2012, s. 26-31).

\section{Podsumowanie}

W polskim systemie pomocy osobom niepełnosprawnym na poziomie regionalnym miejskie (gminne) ośrodki pomocy społecznej pełnią rolę kluczową, stanowiąc, z jednej strony, instytucję odpowiedzialną za wypłatę świadczeń pieniężnych osobom niepełnosprawnym (zasiłki, świadczenia pielęgnacyjne), z drugiej koordynatora i administratora działań z zakresu rehabilitacji społecznej. Wynika to wprost z zapisów ustawowych przytoczonych w niniejszym opracowaniu.

Biorąc pod uwagę istotę społecznego modelu niepełnosprawności, wydaje się, że przyjęta w Polsce konwencja, według której instytucja powołana do realizowania pomocy społecznej, równocześnie ma ten model implementować do praktyki swoich działań, stwarza wiele barier w jego skutecznej realizacji.

Wśród nich kluczową wydaje się swoisty rozdźwięk między możliwościami merytorycznymi, organizacyjnymi i finansowymi, w które miejskie ośrodki pomocy społecznej zostały wyposażone, a zadaniami, które polska polityka społeczna, ustawowymi przepisami, na nie nakłada. Wsparcie osób niepełnosprawnych jest jednym z wielu tych zadań, co w praktyce oznacza, że wśród szerokiego wachlarza obowiązków w pierwszym rzędzie realizowane są głównie te związane z pomocą materialną (wypłata świadczeń), na dalszy plan usuwając pozostałe, związane $\mathrm{z}$ integracją i rehabilitacją społeczną. 
Przybliżenie lokalnych systemów wsparcia osób niepełnosprawnych do społecznego spojrzenia na niepełnosprawność wymaga zatem przede wszystkim działań systemowo-instytucjonalnych i prawnych, których dysponentem jest władza centralna, a nie samorządowa. Zmiany w systemie orzecznictwa oraz podziale kompetencji między instytucje, zarówno w układzie poziomym, jak i wertykalnym to tylko niektóre $\mathrm{z}$ wielu działań, które należy podjąć, by przywrócić osobie niepełnosprawnej podmiotowość, która stanowi podstawę systemu wsparcia opartego na społecznym modelu niepełnosprawności.

\section{Bibliografia}

Barnes C., Mercer G. (2008), Niepetnosprawność, Wydawnictwo Sic!, Warszawa.

Bieganowska A. (2015), Przekaz medialny w modyfikowaniu postaw studentów pedagogiki wobec niepetnosprawności, Wydawnictwo Uniwersytetu Marii Curie-Skłodowskiej, Lublin.

Brząkowski M. (2014), Zatrudnianie niepetnosprawnych, Wydawnictwo C.H. Beck, Warszawa.

Danecki J. (2001), Kwestia społeczna, w: Leksykon polityki społecznej, red. B. Rysz-Kowalczyk, Instytut Polityki Społecznej Uniwersytetu Warszawskiego, Warszawa.

Gałkowski T. (1997), Wokót definicji pojęcia „osoba niepetnosprawna” - doświadczenia europejskie, „Problemy Rehabilitacji Społecznej i Zawodowej”, nr 3 (153).

Gąciarz B. (2014), Model spoleczny niepetnosprawności jako podstawa zmian w polityce społecznej, w: Polscy niepetnosprawni. Od kompleksowej diagnozy do nowego modelu polityki społecznej, red. B. Gąciarz, S. Rudnicki, Wydawnictwo AGH, Kraków.

Gąciarz B., Kubicki P., Rudnicki S. (2014), System instytucjonalnego wsparcia osób niepetnosprawnych $w$ Polsce - diagnoza dysfunkcji, w: Polscy niepetnosprawni. Od kompleksowej diagnozy do nowego modelu polityki społecznej, red. B. Gąciarz, S. Rudnicki, Wydawnictwo AGH, Kraków.

Giełda M. (2015), Pojęcie niepetnosprawności, w: Prawno-administracyjne aspekty sytuacji osób niepetnosprawnych w Polsce, red. M. Giełda, R. Raszewska-Skałecka, Wydział Prawa, Administracji i Ekonomii Uniwersytetu Wrocławskiego, Wrocław.

Golinowska S., Sowa A., Wilmowska-Pietruszyńska A. (2012), Funkcjonowanie orzecznictwa lekarskiego oraz działalność lekarzy orzeczników w systemie zabezpieczenia spolecznego i wspierania zatrudnienia, „Polityka Społeczna”, numer tematyczny 2.

GUS (2011), Bank Danych Lokalnych, NSP, https://bdl.stat.gov.pl/, 10.08.2018. 
Informacja z realizacji Miejskiego Programu Wyrównywania Szans Osób Niepetnosprawnych na lata 2013-2016 za lata: 2013, 2014, 2015, 2016, Urząd Miejski w Koszalinie, Koszalin 2014, 2015, 2016, 2017.

Karaś M. (2012), Niepetnosprawność, od spojrzenia medycznego do społecznego i Disability Studies, „Przegląd Prawniczy, Ekonomiczny i Społeczny”.

Klimczuk A. (2013), Współczesna polityka społeczna wobec niepetnosprawności i osób niepetnosprawnych, „Pogranicze. Studia społeczne”, t. XXII.

Kolwitz M., Radlińska I. (2015), Kształtowanie się współczesnego paradygmatu niepetnosprawności, „Pomeranian Journal of Life Sciences”, nr 61(3).

Konwencja Praw Osób Niepelnosprawnych, art. 1, A/RES/61/106, tłumaczenie z języka angielskiego, http://www.unic.un.org.pl/dokumenty/Konwencja_Praw_ Osob_Niepelnosprawnych.pdf, 28.08.2018.

Krajewski M. (2010), O metodologii nauk $i$ zasadach pisarstwa naukowego. Uwagi podstawowe, Płock.

Kubicki P. (2015), Polityka publiczna wobec niepetnosprawności - propozycje perspektyw teoretycznych, ,Studia z Polityki Publicznej”, nr 4(8).

Ministerstwo Pracy i Polityki Społecznej (2014), Asystent osobisty osoby niepetnosprawnej - rozwiązania w wybranych państwach europejskich, Warszawa.

Supińska J. (2013), Wartości i zasady polityki społecznej, w: Polityka społeczna, red. G. Firlit-Fesnak, M. Szylko-Skoczny, Wydawnictwo Naukowe PWN, Warszawa.

Świetlik B. (2018), Ocena spójności polskiej i unijnej polityki społecznej w zakresie niepetnosprawności, „Studia Ekonomiczne. Zeszyty Naukowe Uniwersytetu Ekonomicznego w Katowicach", nr 353.

Uchwała Sejmu Rzeczypospolitej Polskiej z dnia 1 sierpnia 1997 roku - Karta Praw Osób Niepetnosprawnych, M. P. 1997, Nr 50, poz. 475.

Ustawa 1: Ustawa o rehabilitacji zawodowej i społecznej oraz zatrudnianiu osób niepetnosprawnych, Dz. U. 1997, Nr 123, poz. 776.

Ustawa 2: Ustawa z dnia 12 marca 2004 o pomocy społecznej, art. 2.1., art. 112.1, Dz. U. 2004, Nr 64, poz. 593, tekst jednolity.

Vademecum dla osób niepetnosprawnych - przewodnik zawodowy (2009), Część I: Podstawowe pojęcia, Centrum Informacji i Planowania Kariery Zawodowej, Kraków.

Waszczak S. (2000), Stosunek społeczeństwa do osób niepetnosprawnych, „Problemy polityki społecznej. Studia i dyskusje", nr 2.

Wiliński M. (2010), Modele niepetnosprawności: indywidualny-funkcjonalny-społeczny, w: Diagnoza potrzeb i modele pomocy dla osób z ograniczeniami sprawności, red. A. I. Brzezińska, R. Kaczan, K. Smoczyńska, Wydawnictwo Naukowe SWPS Academica, Warszawa.

Woźniak Z. (2008), Niepetnosprawność $i$ niepetnosprawni $w$ polityce społecznej. Społeczny kontekst medycznego problemu, Wydawnictwo Szkoły Wyższej Psychologii Społecznej Academica, Warszawa. 
Woźniak-Szymańska A. (2011), Dobre praktyki. Wybrane ustugi świadczone na rzecz osób niepetnosprawnych we Francji, Szwecji oraz Niemczech, Koalicja na Rzecz Osób Niepełnosprawnych.

Wóycicka I. (red.) (2010), Skuteczność lokalnego systemu wsparcia na rzecz osób integracji spolecznej i zawodowej osób niepetnosprawnych, Instytut Badań nad Gospodarką Rynkową, Gdańsk.

\title{
Institutional support of people with disabilities in Koszalin on the example of activities of the Municipal Family Assistance Center in 2013-2016 and the social model of disability
}

\begin{abstract}
Summary
The social model of disability is now the dominant perspective taken in Europe on the essence of disability and people affected by it. In 1997, Poland adopted the Resolution of the Parliament on the Charter of Rights of Disabled Persons and joined the Convention on the Rights of Persons with Disabilities in 2012, thereby assuming an obligation to adopt this perspective in its regulations and actions for people with disabilities. The aim of the article was to analyze and evaluate the activities of the Municipal Family Assistance Center (MOPR) in Koszalin in 2013-2016 as a key institution in the local support system for people with disabilities. To accomplish the goal, the following thesis was adopted: at the local level, the Polish system of institutional support for the disabled does not fully meet the assumptions of the social model of disability. The description of the activity of MOPR in Koszalin in the article confirmed the thesis, pointing to the legal and institutional barriers to effective assistance for disabled people in accordance with the social model of disability.
\end{abstract}

Key words: support for people with disabilities, disability, social disability model, social policy, rehabilitation 